Jurnal Konstruksi Hukum | ISSN: XXXX | E-ISSN: XXXX Vol. 1, No. 2, Oktober 2020, Hal. 393-398| Available Online at https://www.ejournal.warmadewa.ac.id/index.php/jukonhum DOI: https://doi.org/10.22225/jkh.1.2.2540.393-398

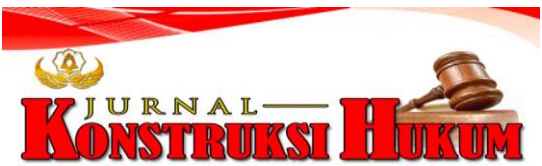

\title{
FUNGSI SATUAN POLISI PAMONG PRAJA DALAM PENEGAKAN KAWASAN JALUR HIJAU DI KABUPATEN KLUNGKUNG
}

\author{
I Komang Subagiarta \\ Fakultas Hukum Universitas Warmadewa, Denpasar - Bali, Indonesia
}

\begin{abstract}
Abstrak
Satuan Polisi Pamong Praja merupakan lembaga yang dibentuk oleh pemerinta sebagai perangkat daerah sehingga keberadaannya memiliki posisi yang strategis dalam penyelenggaraan pemerintahan daerah guna menciptakan ketertiban, keteraturan, dan ketaatan masyarakat daerah terhadap peraturan daerah. Oleh karena itu, fungsi Satuan Polisi Pamong Praja adalah sebagai penegak peraturan daerah, yang salah satunya ialah penegakan peraturan daerah tentang kawasan jalur hijau, namun pelaksanaannya mengalami berbagai kendala. Untuk mengatasi hal tersebut, sebuah kajian ilmiah mempunyai posisi untuk mengisi celah, maka penelitian ini bertujuan untuk upaya mengungkap fungsi sebenarnya dari SATPOL PP dan kendala hukum pelaksanaan kegiatannya. Untuk mengungkap hal itu, penelitian ini didesain dengan menggunakan desain metode penelitian huku normatif. Data dikumulkan menggunakan teknik studi dokumen dan dianalisis menggunakan teknik argumentasi hukum. Hasil penelitian menunjukkan bahwa fungsi SatPol PP dalam penegakan peraturan kawasan jalur hijau di Kabupaten Klungkung adalah fungsi pembinaan, fungsi pengendalian dan fungsi pengawasan terhadap penyelenggaraan ketertiban umum terkait kawasan jalur hijau. Pelaksanaan fungsi SatPol PP dalam penegakan peraturan jalur hijau belum maksimal karena masih terdapatnya beberapa kendala, yaitu pihak SatPol PP Kabupaten Klungkung belum dapat bertindak penuh dalam penegakan hukum peraturan jalur hijau di wilayah Kabupaten Klungkung, kurangnya personil yang melakukan kegiatan penataan, pembinaan dan penertiban, dan kurangnya kesadaran masyarakat terhadap peraturan yang berlaku terkait dengan kawasan jalur hijau.
\end{abstract}

Kata kunci: Fungsi Satpol PP; Kawasan Jalur Hijau; Ketertiban Umum

\begin{abstract}
The Indonesian Civil Service Police Unit (Satpol PP) appears as an institution established by the government as a regional apparatus that its existence has a strategic position in the administration of regional government in order to create order, security, and obedience to local communities to regional regulations. Therefore, the function of the Satpol PP is to enforce regional regulations, one of which is the enforcement of local regulations regarding green line areas, but their implementation has encountered various obstacles. To help overcome this, a scientific study has a position to fill in the gap in the form of the absence of efforts to reveal the major function of Satpol PP and the legal obstacles to implementing its activities. To reveal this, the present study was designed using a normative legal research method design. Data were collected using a document study technique and analysed using a legal argumentation technique. The results showed that the function of SatPol $P P$ in enforcing green line area regulations in Klungkung Regency is the functions of guidance, control function and supervision of the implementation of public order related to the green line area. The realisation of the SatPol PP function in enforcing the green line regulation has not been maximally executed because there are still several obstacles, such as the Klungkung Regency SatPol PP has not been able to take full action in enforcing the green line regulation law in the Klungkung Regency area, the lack of personnel carrying out structuring, the limited coaching and controlling activities, and lthe ack of public awareness of applicable regulations related to green line areas.
\end{abstract}

Keywords: The function of Satpol PP, Green Line Area, Public Order

\section{PENDAHULUAN}

Negara Indonesia adalah hukum yang berlandaskan pada Pancasila dan Undnag-Undang Dasar 1945 dalam setiap pengambilan keputusan terkait dengan penegakan hukum. Dalam implementasinya setiap warga negara memiliki kesetaraan dalam penerimaan hak asasi manusia serta perlakuan yang 
sama adilnya di depan mata hukum (Hartati, 2009). Sebagai negara hukum setiap anggota masyarakat berhak untuk menerima keadilan yang sama rata serta adanya kedudukan yang sama di depan hukum tersebut. Hukum adalah sebagai kunci dari terciptanya masyarakat yang beradab, damai dan sentosa. Adanya hukum dapat menjadi salah satu ujung tombak terbentuknya suatu negara yang madani dan mampu mensejahterakan anggota masyarakatnya. Dalam penegakan hukm ada satu kunci pokok yang harus dimiliki oleh setiap negara yaitu keberadaan dari aparat penegak hukum sebagai lini pertahanan hukum itu sendiri (Ali, 2007) Para pejabat pemerintah yaitu aparatur penegak hukum memiliki fungsi dan wewenang dalam upaya penegakan hak asasi manusia adalah untuk menjaga perdamaian dan ketertiban di masyarakat yang mungkin di dalamnya ada pelanggaran hak asasi manusia sehingga dapat menimbulkan kekacauan di masyarakat itu sendiri. Penegakan hukum di sini termasuk polisi, kejaksaan, kehakiman, dan juga termasuk Unit Sipil Kepolisian (Satpol PP) yang tiada lain adalah bagian dari aparat penegak hukum non-yudisial di daerah.

Dalam beberapa tahun terakhir, langkah polisi kota tidak pernah luput dari perhatian publik. Munculnya citra miring dari sosok pasukan polisi kota adalah hasil dari tindakan represif, tetapi tampak arogan dari petugas daerah saat melakukan peran mereka dalam menjaga dan mengatur keamanan dan ketertiban umum. Pemberian wewenang kepada polisi kota untuk menjaga keamanan dan ketertiban masyarakat bukan tanpa alasan. Namun, didukung oleh yayasan yuridis yang jelas. Tapi hasil ini sering konfik antara polisi kota dan masyarakat. Keberadaan Satpol PP di Kabupaten Klungkung merupakan bagian dari proses peradilan sebagai alat pemerintah daerah diperlukan untuk mendukung keberhasilan pelaksanaan otonomi daerah. Dalam menjalankan fungsinya, kewenangan polisi kota sering tumpang tindih dan berbenturan dengan penegak hukum lainnya, terutama polisi. Jika dilihat secara umum dalam Peraturan Pemerintah Republik Indonesia Nomor 16 Tahun 2018 Tentang fungsi polisi kota Satuan Polisi Pamong Praja dalam melakukan penyusunan program penegakan dan koordinasi pelaksanaan regulasi dan Perkada, penyelenggaraan ketertiban umum dan perdamaian dan pelaksanaan perlindungan masyarakat serta untuk mengawasi masyarakat, aparatur, atau badan hukum untuk pelaksanaan undang-undang dan Perkada.

Anda beberapa tahun terakhir, isu konversi lahan kawasan sabuk hijau terutama dalam sorotan. Sesuai Peraturan Kabupaten Klungkung No 1 tahun 2013 salah satu fungsi dan kewenangan polisi kota Kabupaten Klungkung sesuai dengan peraturan ini adalah untuk memberikan bimbingan, pengendalian dan pengawasan teknis terkait dengan kehadiran daerah sabuk hijau. Dalam konteks ini, pencegahan alih fungsi kawasan jalur hijau dilakukan karena mengacu pada peraturan Klungkung Nomor 1 tahun 2013 Pasal 81 menyatakan bahwa paling sedkit 40 persen dari dari luas Urban Semarapura adalah ruang terbuka hijau, setidaknya 50 persen dari Daerah Perkotaan Sampalan dan Ex Perkotaam Daerah Material Mining Group C, setidaknya 60 persen dari Daerah Perkotaan Banjarangkan Daerah Perkotaan dan Dawan dengan proporsi masing-masing 20 persen dari Kota publik Ruang Terbuka Hijau; sedangkan Ruang Terbuka Hijau di Daerah Pedesaan di kurangnya 70 persen dari daerah pedesaan. Salah satu dari kasus-kasus yang baru-baru ini terjadi di Klungkung dalam jalur hijau di Subak delod Banjarangkan, Kabupaten Banjarangkan. Dalam upaya untuk mengatasi hal ini Kasatpol PP Klungkung dan anggota, telah melakukan bebarapa tindakan, yang dimulai dengan memberikan banding ke publik, panduan lebih lanjut dan pengawasan masyarakat untuk tidak menggunakan daerah sebagai daerah perumahan sabuk hijau. Polisi kota dalam hal ini hanya dapat menjalankan fungsi dan tanggung jawab dalam hal pembinaan dan pengawasan sehingga nantinya atas tanah sebagai lahan tempat tinggal menyebar. Hal ini menunjukkan bahwa ada kekaburan norma, yang merupakan ketidakpastian hukum dalam kasus-kasus penegakan hukum yang berkaitan dengan daerah sabuk hijau.

Beranjak dari uraian di atas, ditemukan norma kabur (tidak jelas van normen) pada fungsi polisi kota di daerah sabuk hijau penegakan hukum. Dalam ketentuan umum Pasal 41 tidak disebutkan fungsi spesifik polisi kota di daerah sabuk hijau penegakan hukum. Kondisi norma disebut norma adalah karena ketidakjelasan undang-undang telah tersedia namun perumusan kata atau kalimat yang kurang jelas, menyebabkan kabur gagasan. Ketidakjelasan norma ini dapat menyebabkan multitafsir dari Pasal dalam hukum dan menimbulkan ketidakpastian hukum. Jika ini terus berlanjut, maka hukum yang ada tidak dapat diimplementasikan secara efektif.

Berdasarkan uraian di atas, maka Penelitian ini dilakukan dengan tujuan untuk mengetahui fungsi satuan polisi pamong praja dalam penegakan peraturan kawasan jalur hijau di Kabupaten Klungkung menurut Perda Nomor 2 Tahun 2014, Untuk mengetahui kendala hukum pelaksanaan fungsi satuan 
polisi pamong praja dalam penegakan peraturan kawasan jalur hijau di Kabupaten Klungkung menurut Perda Nomor 2 Tahun 2014.

\section{METODE PENELITIAN}

Penelitian ini adalah penelitain penelitian hukum normatif yang mengkaji permasalahan dari peraturan perundang-uandangan dan menggunakan pendekatan masalah dan pendekatan konsep hukum. Bahan Primer dan dan Sekunder digunakan dalam pengumpulan bahan hukum. Bahan hukum primer yang terdiri atas Undang-Undang dan peraturan lainnya serta hukum sekunder yang berasal dari literatur hukum. Teknik studi dokumen adalah teknik yang dipilih peneliti dalam upaya menjawab permasalahan dalam penelitian ini. Analisis bahan hukum dilakukan dengan menggunakan argumen hukum yang disajikan secara deskriptif. Bahan dikumpulkan, kemudian diolah dan dianalisis menggunakan argumen hukum untuk menjawab permasalahan yang diajukan, untuk persiapan deskriptif yaitu dengan mengatur materi hukum yang telah secara sistematis sehingga membentuk suatu karya ilmiah (Soekanto \& Mamudji, 2003).

\section{HASIL DAN PEMBAHASAN}

Fungsi Satuan Polisi Pamong Praja dalam Peraturan Metro Green Line Penegakan di Klungkung Dalam memahami pengaturan masalah mengenai fungsi Unit Pelayanan Sipil di daerah jalur hijau penegakan akan memerlukan pemahaman tentang Teori Penegakan Hukum. Dalam Undang-Undang Republik Indonesia Tahun 1945, Pasal 1 ayat (3) menyatakan bahwa Indonesia adalah negara hukum. Formulasi eksplisit dari teori penegakan hukum yang berarti bahwa hukum adalah dalam komandan negara. Menurut Soerjono Soekanto, konseptual penegakan hukum terletak pada harmonisasi kegiatan hubungan yang terjabarkan dari nilai-nilai dalam aturan yang mewujudkan sikap mantap dan bertindak sebagai rangkaian terjemahan dari nilai tahap akhir, untuk menciptakan, memelihara, dan memelihara perdamaian sosial hidup (Soekanto, 2004). Dalam melaksanakan penegakan peraturan daerah sebagaimana dimaksud dalam Pasal 8 Peraturan Pemerintah Nomor 16 Tahun 2018 tentang Satuan Polisi Pamong Praja menyatakan bahwa penyidik polisi kota untuk bertindak sebagai koordinator di pemerintah daerah. Dalam Pasal 11 menyatakan bahwa pelaksanaan ketertiban umum dan polisi kota ketentraman masyarakat dilakukan kegiatan meliputi 1) deteksi dan pencegahan dini; 2) bimbingan dan konseling; 3) patroli; 4) keamanan; 5) mengawal; 6) kepolisian; dan 7) penanganan protes dan kerusuhan. Dalam upaya untuk mencapai lingkungan yang tertib dan nyaman, sehubungan dengan kinerja aparatur Satpol PP yang bertanggung jawab untuk mewujudkan kondisi ini. Menurut Pasal 148 ayat (1) Undang-Undang Nomor 32 Tahun 2004 tentang Pemerintahan Daerah:

Kondisi keamanan dan ketertiban yang didirikan di masyarakat akan mendorong terciptanya stabilitas nasional dan akan memastikan pemerintahan yang mulus di wilayah dan pelaksanaan pembangunan daerah itu adalah tugas Kepala Daerah akan meningkat, terutama dalam menegakkan Peraturan Daerah dan pelaksanaan Ketertiban Umum dan ketenangan masyarakat dibentuk Satuan Polisi Pamong Praja.

Dalam melaksanakan tugas pokok dan fungsi, Satuan Polisi Pamong Praja merupakan salah satu unsur pendukung tugas Bupati di bidang penegakan peraturan daerah, Peraturan Kepala Daerah, ketertiban umum dan ketenangan masyarakat dan perlindungan masyarakat. Satuan Polisi Pamong Praja untuk memiliki tugas memelihara dan mengatur ketentraman masyarakat dan ketertiban umum dan melindungi masyarakat, dan karena itu tugas yang dimiliki oleh polisi kota dalam Peraturan Pemerintah Nomor 16 Tahun 2018 tentang Satuan Polisi Pamong Praja (Pasal 5 ) adalah:

1. menegakkan undang-undang dan Perkada;

2. mengorganisir ketertiban umum dan perdamaian;

3. mengorganisir perlindungan publik.

Dalam melaksanakan tugas sebagaimana dimaksud dalam Pasal 5, polisi kota memiliki fungsi (Pasal 6):

1. Penyusunan undang-undang dan program penegakan Perkada, pelaksanaan ketertiban umum dan perdamaian dan penyelenggaraan perlindungan masyarakat;

2. Perda implementasi kebijakan penegakan dan Perkada, mengorganisir ketertiban umum dan perdamaian publik dan penyelenggaraan perlindungan publik

3. Mengkoordinasikan penegakan hukum dan Perkada, mengorganisir ketertiban umum dan perdamaian dan penyelenggaraan perlindungan publik dengan instansi terkait. 
4. Pengawasan masyarakat, aparatur, atau badan hukum untuk pelaksanaan undang-undang dan Perkada; dan

5. Pelaksanaan fungsi lainnya berdasarkan pada tugas-tugas yang diberikan oleh kepala daerah sesuai dengan ketentuan peraturan perundang-undangan.

Satuan Polisi Pamong Praja (Satpol PP) adalah perangkat lokal dalam menjaga keamanan dan ketertiban umum dan menegakkan peraturan daerah. Peran sebagai personel polisi kota dalam menjaga ketertiban umum dan berkaitan dengan perencanaan tata ruang di kabupaten/ kota. Berdasarkan Peraturan Daerah Klungkung Nomor 2 Tahun 2014 tentang Ketertiban Umum, dalam Pasal 2 Peraturan menjelaskan bahwa satu set dalam UU ini adalah urutan sabuk hijau, taman dan tempat umum. Garis hijau adalah setiap jalur terbuka sesuai dengan rencana pemerintah yang ditunjuk pengaturan dan pengawasan oleh pemerintah daerah. Dalam Pasal 11 ayat a dan b dijelasakan bahwa setiap orang atau badan dilarang:

a. Membangun dan bertempat tinggal di daerah jalur hijau;

b. Melakukan alih fungsi jalur hijau;

Di Klungkung Peraturan Daerah Nomor 2 Tahun 2014 tentang Ketertiban Umum Pasal 21 (1b) telah dikonfirmasi bahwa setiap orang atau badan dilarang membangun di sebelah kanan jalan, ruang milik sungai, taman dan jalur hijau, kecuali untuk kepentingan tugas. Penataan ruang dan Pengelolaam dalam kehidupan manusia yang dianggap sebagai wadah untuk mencapai peningkatan lingkungan, bukan justru sebaliknya (AM, 2014). Artinya, aktivitas yang dihasilkan dari pengembangan tata ruang harus menggunakan bernuansa sumber daya alam tanpa merusak lingkungan. Pembangunan merupakan upaya yang dilakukan untuk menjadikan baik itu wilayah maupun masyarakatnya menjadi lebih maju, mandiri dan sejahtera (Mitchell, 2010). Meningkatnya permintaan untuk ruang, terutama untuk lahan perumahan dan berkembang berdampak pada penurunan ketersediaan ruang terbuka hijau, ruang terbuka hijau terutama publik (Zoer'aini, 2007). Baru saja pada awal tahun tepatnya Januari 2018 pelanggaran Peraturan Daerah Klungkung Nomor 2 tahun 2014 tentang Ketertiban Umum terkait dengan konversi lahan di daerah sabuk hijau di Kabupaten Klungkung. Dilansir dari BaliPost.com (2018), pada awal Januari 2018 terjadi tepatnya selama kasus jalur hijau di Subak delod Banjarangkan, Kabupaten Banjarangkan.

Berdasarkan contoh kasus yang berkaitan dengan pelaksanaan ketertiban umum, Peraturan Klungkung Nomor 2 tahun 2014 tentang Ketertiban Umum dalam Pasal 41 menjelaskan bahwa bimbingan, pengendalian dan pengawasan pelaksanaan ketertiban umum oleh Bupati dan diimplementasikan secara teknis dilaksanakan oleh Satuan Polisi Pamong Praja bersama dengan Penyidik pegawai negeri sipil di lingkungan pemerintah Kabupaten Klungkung sesuai dengan hukum dan peraturan. Mengacu pada aturan fungsi polisi kota dalam administrasi ketertiban umum di Kabupaten Klungkung menjalankan fungsi pembinaan, pengendalian dan pengawasan penegakan hukum, termasuk daerah sabuk hijau. Dalam Peraturan Kabupaten Klungkung Nomor 1 Tahun 2013 tentang Penataan Ruang Kabupaten Klungkung Tahun 2013-2033, khususnya Pasal 109 (2) menyatakan bahwa menjelaskan bahwa membatasi pelanggaran pemanfaatan ruang dan pengendalian gangguan ketertiban umum yang dilakukan oleh Penyidik Pegawai Negeri Sipil (peneliti) dan Satuan Polisi Pamong Praja. Sehubungan dengan hal tersebut, menegaskan kembali bahwa Satuan Polisi Pamong Praja memiliki fungsi pengendalian pemanfaatan pelanggaran ruang dan ketertiban umum lainnya, termasuk daerah jalur hijau.

Ada tidaknya kedamaian di suatu kota akan menjadi tanggung jawab dari semua pihak, mulai dari masayarakat dan pemerintah. Untuk itu maka perlu diberlakukan suatu kebijakan sadar, yang artinya peningkatan kerjasama yang baik. Sebagai masyarakat kita harus menghormati para penegak hukum, begitu pula sebaliknya, aparat penegak hukum seyogyanya mampu menghormati masyarakat dalam pemberian pelayanan. Daerah yang mentaati peraturan hukum niscaya akan lebih cepat dalam mencapai kemakmuran. Satpol PP sebagai lini pengamanan di lingkungan yang memiliki tugas menjaga ketertiban umum seyogyanya tidak dipandang sebelah mata dan turut dihormati sebagai aparatur penegak hukum.

Mengacu pada beberapa undang-undang dari Peraturan Pemerintah Nomor 16 Tahun 2018 tentang Satuan Polisi Pamong Praja, Peraturan Daerah Klungkung Nomor 2 tahun 2014 tentang Ketertiban Umum dan Perda Klungkung Nomor 1 Tahun 2013 tentang Rencana Tata Ruang Kabupaten Klungkung pada tahun 2013 -2033 dapat disimpulkan bahwa fungsi polisi kota adalah 
undang-undang penegakan dan Perkada, mengorganisir ketertiban umum dan perdamaian dan penyelenggaraan perlindungan publik. Ruang lingkup fungsi dan tugas Polres dalam membina perdamaian dan masyarakat pada dasarnya cukup luas, jadi kita memerlukan baik jumlah anggota, kesiapan personil, kualitas personel termasuk kejujuran dalam melaksanakan tugasnya. Berdasarkan undang-undang fungsi polisi kota yang ada hanya sampai pada tahap pembongkaran dan konstruksi, tetapi tidak untuk menindaklanjuti secara hukum.

\section{Kendala Pelaksanaan Fungsi Satuan Polisi Pamong Praja dalam Penegakan Peraturan Jalur Hijau di Kabupaten Klungkung}

Satuan Polisi Pamong Praja memiliki tugas dan fungsi membantu Kepala Daerah untuk menciptakan kondisi daerah yang damai, tertib, dan teratur sehingga organisasi roda pemerintahan berjalan lancar dan orang dapat melakukan aktifitasnya dengan aman. Berkaitan dengan keberadaan Satuan Polisi Pamong Praja dalam penegakan hukum sebagai pemerintah daerah, pegawai negeri kontribusi satuan polisi diperlukan untuk mendukung keberhasilan pelaksanaan otonomi daerah di bidang penegakan menciptakan pemerintahan yang baik. Jadi Polisi Kota adalah garis depan dalam memastikan pelaksanaan suara peraturan daerah dan upaya untuk menegakkan hukum di tengah-tengah masyarakat, sambil membantu untuk menindak segala bentuk penyalahgunaan dan penegakan hukum.

Dengan memperhatikan tugas dan fungsi Satuan Polisi Pamong Praja, maka mereka diwajibkan untuk memperbaiki dan mengatur berbagai sektor yang masih lemah dengan mempertahankan dan meningkatkan dan pemeliharaan yang mapan melalui pola pembinaan yang tepat dan lebih konkret untuk Sipil kepolisian unit, sehingga peran polisi Satuan Municipal dapat memberikan manfaat di semua bidang termasuk pemerintahan dan pembangunan sosial. Kesadaran bahwa di masa depan tingkat pengembangan cenderung untuk meningkatkan kapasitas dan intensitas serta lebih kompleks masalah, itu akan berdampak pada kehidupan masyarakat dengan tingkat permintaan cenderung meningkat juga. Ketertiban umum dan ketentraman masyarakat mengalami beberapa kendala oleh adanya perbedaan presepsi dalam mengimplementasikan aturan tersebut yang menyebabkan terjadinya suatu konflik yang menyebabkan kekaburan fungsi dari aparatur polisi pamong praja. Hal ini karena adanya perbedaan pressepsi sosial dibenak masyarakat terkait dengan keberadaan satpol PP dan polisi (Ali, 1998) Isu ini dapat menjadi kendala bagi Satpol PP ketika terjun menjalankan tugasnya dilapangan.

Dalam melaksanakan fungsi manajemen, kontrol dan pengawasan penegakan hukum di Jalur Hijau Peraturan Klungkung Satuan Polisi Pamong Praja memiliki beberapa masalah sebagai berikut.

1) Kendala dari undang-undang itu sendiri, yang artinya bahwa Satuan Polisi Pamong Praja Klungkung tidak bisa bertindak sepenuhnya dalam penegakan hukum peraturan kawasan jalur hijau di Kabupaten Klungkung. Hal ini karena aturan yang menyebutkan bahwa Satuan Polisi Pamong Praja hanya memiliki fungsi dalam kontrol dan bimbingan, serta berkoordinasi dengan polisi dan lainnya otoritas, tetapi tidak untuk menindaklanjuti secara hukum. Hal ini juga dapat dilihat dari Peraturan Kabupaten Klungkung Nomor 2 tahun 2014 tentang Ketertiban Umum Pasal 41 menjelaskan bahwa fungsi dan peran polisi kota dalam administrasi ketertiban umum di Kabupaten Klungkung menjalankan fungsi pembinaan, pengendalian dan pengawasan penegakan hukum, termasuk daerah kawasan jalur hijau.

2) Masih lemahnya koordinasi yang dilakukan oleh Satuan Polisi Pamong Praja di Kabupaten Klungkung dengan otoritas lainnya untuk menjelaskan masalah jalur hijau sehingga fungsi dan peran polisi kota di daerah disiplin jalur hijau masih sangat minim dan pengambilan terbatas sulit untuk menciptakan kondisi yang tertib dan damai seperti yang diharapkan.

3) Kurangnya kesadaran masyarakat akan peraturan yang berkaitan dengan daerah jalur hijau. Artinya, meskipun telah diberlakukan aturan mengenai pembatasan wilayah sabuk hijau, tetapi masih ada kasus penggunaan lahan di kawasan sabuk hijau.

4) Masih kurangnya personil yang melakukan kegiatan permukiman, pembinaan dan penertiban bahwa hasil yang diperoleh kurang maksimal. 


\section{SIMPULAN DAN SARAN}

\section{Simpulan}

Berdasarkan penjelasan yang telah dijelaskan sebelumnya, serta masalah dalam penelitian ini, dapat disimpulkan bahwa jawaban untuk masalah ini adalah sebagai berikut:

1) Fungsi Satuan Polisi Pamong Praja dalam penegakan hukum di daerah kawasan jalur hijau di Kabupaten Klungkung adalah pembinaan, pengendalian dan pengawasan dari pelaksanaan ketertiban umum yang berkaitan dengan daerah jalur hijau. Selanjutnya berdasarkan undangundang fungsi polisi kota yang ada hanya sampai pada tahap memberi himbauan dan kontrol, tetapi tidak untuk menindaklanjuti secara hukum.

2) Kendala dalam penegakan peraturan kawasan jalur hijau di Kabupaten Klungkung terdiri atas kendala yang merupakan kendala dari undang-undang itu sendiri. Artinya, dalam peraturan, Satuan Polisi Pamong Praja Klungkung tidak bisa bertindak sepenuhnya dalam penegakan hukum peraturan kawasan jalur hijau hijau di Kabupaten Klungkung. Hal ini karena Satuan Polisi Pamong Praja hanya memiliki fungsi pengendalian dan pembinaan, tetapi tidak untuk menindaklanjuti secara hukum. Kendala lainnya adalah kurangnya kesadaran masyarakat akan peraturan yang berkaitan dengan daerah jalur hijau dan kurangnya personil yang melakukan kegiatan permukiman, pembinaan dan penertiaban bahwa kadang-kadang hasil yang diperoleh kurang maksimal.

\section{Saran}

Saran-saran yang dapat disampaikan berdasarkan hasil analisis adalah sebagai berikut:

1) Pelaksanaan kewenangan polisi kota harus sesuai untuk tugas-tugas dan fungsi polisi kota, yang merupakan undang-undang aparat penegak hukum khusus, penyelenggara ketertiban umum dan ketenangan masyarakat dan perlindungan masyarakat dan tidak hanya bisa digunakan selama pelaksanaan atau pengawasan /mengawal saja. Dengan demikian, pelanggaran yang berkaitan dengan daerah jalur hijau dapat diminimalkan.

2) Agar kinerja Satpol PP dapat mengedepankan fungsinya maka diperlukan tenaga fungsional khusus dari departemen Satpol PP yang ditugaskan khusus untuk mengawasi penegakan hukum jalur hijau. Selain itu, juga perlu adanya peningkatan keterampilan anggota melalui pendidikan dan pelatihan yang berkelanjutan sehingga polisi kota memiliki kinerja yang optimal dalam menciptakan ketertiban umum.

\section{DAFTAR PUSTAKA}

Ali, A. (1998). Menjelajahi Kajian Empiris. Makassar: Kencana.

Ali, Y. (2007). Dasar-Dasar Ilmu Hukum. Jakarta: Sinar Grafika.

AM, Y. W. (2014). Pengantar Hukum Tata Ruang. Jakarta: Fajar Interpratama Mandiri.

Hartati, E. (2009). Tindak Pidana Korupsi. Jakarta: Sinar Grafika.

Mitchell, B. (2010). Pengelolaan Sumber Daya dan Lingkungan (Cetakan Ke). Yogyakarta: Gajah Mada University Press.

Soekanto, S. (2004). Faktor-Faktor Yang Mempengaruhi Penegakan Hukum (Cetakan Ke). Jakarta: Raja Grafindo Persada.

Soekanto, S., \& Mamudji, S. (2003). Penelitian Hukum Normatif: Suatu Tinjauan Singkat. Jakarta: Rajawali Press.

Zoer`aini, J. . (2007). Tantangan Lingkungan dan Lansekap Hutan Kota. Jakarta: Bumi Aksara. 